\title{
Map of locations referred to in this book
}

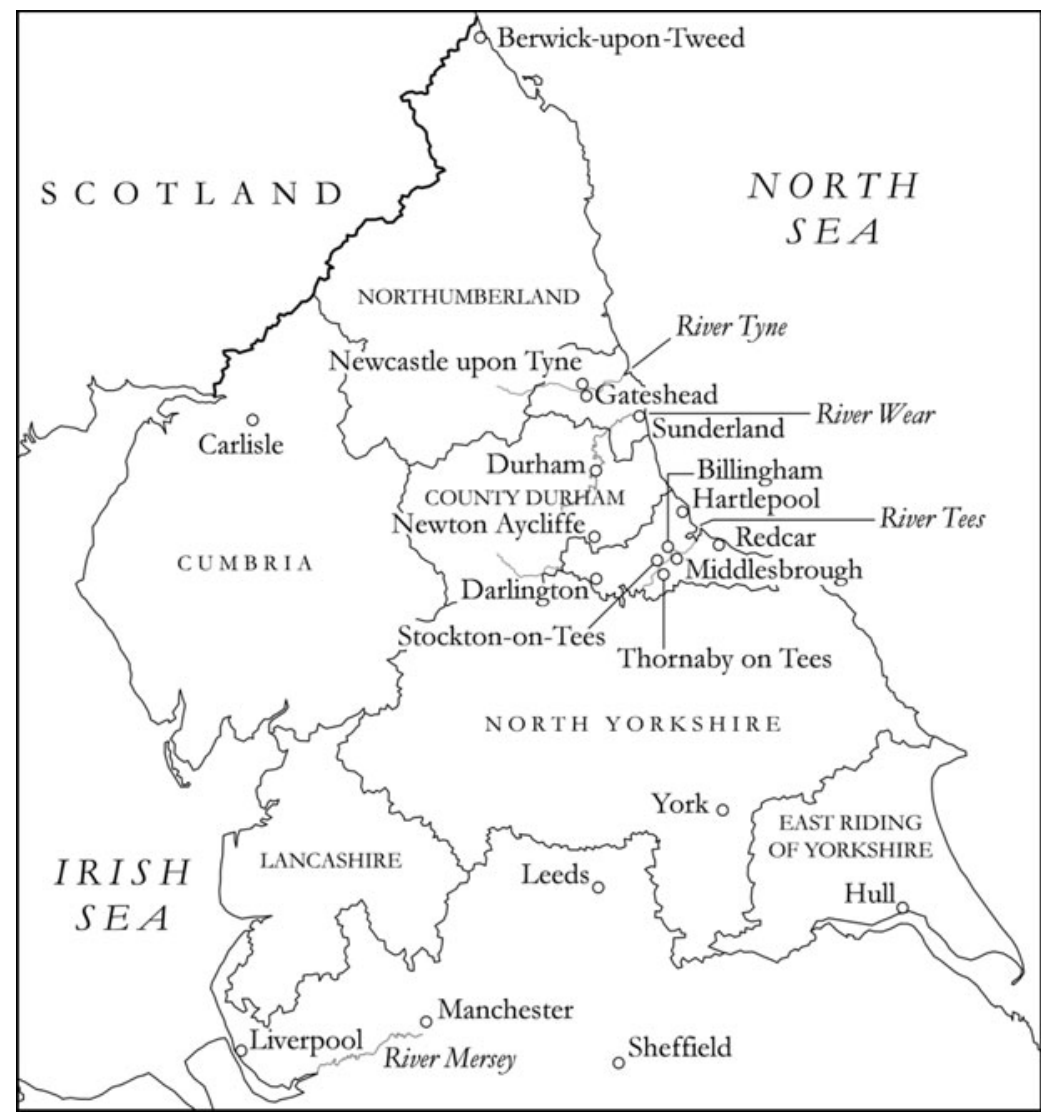


